\title{
ANALISIS KEMAMPUAN PENALARAN MATEMATIS DITINJAU DARI GAYA BELAJAR SISWA
}

\author{
Nur Harini Khoirun Nisa \\ SMPIT Al-Falah Bandungan, Indonesia \\ Email:nbknisa09@gmail.com
}

\begin{abstract}
The purpose of this study was to determine the profile of students' mathematical reasoning abilities, profiles of visual, auditory, kinesthetic learning styles and the correlation of reasoning abilities with students' learning styles. This type of research is a non-experimental quantitative research using the correlation method. The technique used in obtaining the data for this study was a learning style questionnaire and a test of students' mathematical reasoning abilities. The research subjects were students of class VIII SMPIT Al-Falah Bandungan with a total of 89 students. The results of this study showed that the profile of students' mathematical reasoning abilities of class VIII SMPIT was in the medium category with a percentage of $50 \%$. For the profile of the learning style of class VIII SMPIT students, the trend of learning style is visual learning style with a percentage of $40 \%$, auditory learning style by $37 \%$, and as many as 17\% have a kinesthetic learning style, and there are 2 students who have a combined learning style, namely learning styles visual-kinesthetic and visual-auditorial. Then the relationship between mathematical reasoning ability and student learning style is in a strong interval with a value of 0.4536464 and a significant correlation level of 2.561 with a relationship level of $19 \%$, it proves that $19 \%$ of students' mathematical reasoning ability is determined by learning style, and the rest is determined by factors other.
\end{abstract}

Keywords: mathematical reasoning, learning style.

\begin{abstract}
Abstrak
Tujuan penelitian ini adalah untuk mengetahui profil kemampuan penalaran matematis siswa, profil gaya belajar visual, auditorial, kinestetik dan korelasi kemampuan penalaran dengan gaya belajar siswa. Jenis penelitian adalah penelitian kuantitatif non eksperimen menggunakan metode korelasi. Teknik yang digunakan dalam memperoleh data penelitian ini menggunakan angket gaya belajar dan tes kemampuan penalaran matematis siswa. Subjek penelitian adalah siswa kelas VIII SMPIT Al-Falah Bandungan dengan jumlah 89 siswa. Hasil penelitian ini diperoleh bahwa profil kemampuan penalaran matematis siswa kelas VIII SMPIT berada pada kategori sedang dengan persentase $50 \%$. Untuk profil dari gaya belajar siswa kelas VIII SMPIT, kecendurungan gaya belajarnya adalah gaya belajar visual dengan persentase $40 \%$, gaya belajar auditori sebesar $37 \%$, dan sebanyak $17 \%$ memiliki gaya belajar kinestetik, dan terdapat 2 siswa yang memiliki gaya belajar gabungan, yaitu gaya belajar visual-kinestetik dan visual-auditorial. Kemudian hubungan kemampuan penalaran matematis terhadap gaya belajar siswa berada padainterval kuat dengan nilai 0,4536464 d an taraf signifikan korelasi sebesar 2,561 dengan tingkat hubungan sebesar 19\% hal tersebut membuktikan kalau 19\% kemampuan penalaran matematis siswa ditentukan oleh gaya belajar, dan sisanya ditentukan oleh faktorlain.
\end{abstract}

Kata kunci: penalaran matematis, gaya belajar. 


\section{PENDAHULUAN}

Matematika memegang peranan penting dalam menciptakan sumber daya manusia (SDM) yang berkualitas, sebab dalam matematika terkandung berbagai konsep yang logis dan realistis yang mampu membentuk pola pikir manusia dalam pengembangan ilmu pengetahuan dan teknologi (Latif dan Irwan, 2016:208). Matematika bukan sekedar pelajaran tentang berhitung dan menghafal rumus tetapi matematika mengajarkan siswa agar dapat menyelesaikan berbagai masalah matematis yang berkaitan dengan kehidupan nyata dan berpengaruh dalam kehidupan sehari-hari.

Matematika dan penalaran merupakan dua hal yang tidak dapat dipisahkan, matematika dipahami melalui penalaran dan penalaran dilatih melalui belajar matematika (Handayani, 2013:161). Penalaran dalam matematika dapat membantu individu untuk tidak sekedar mengingat fakta, aturan, dan langkah penyelesaian-penyelesaian masalah, tetapi menggunakan keterampilan bernalarnya dalam melakukan pendugaan atas dasar pengalamanya sehingga yang bersangkutan akan memperoleh pemahaman konsep matematika yang saling berkaitan dan belajar secara bermakna (Baroody dan Nasution dalam Ardhiyanti, Sutriyono dan Fika, 2019:91). Kemampuan dalam bernalar menjadikan siswa dapat memecahkan masalah dalam kehidupannya, di dalam dan di luar sekolah. Kapanpun kita menggunakan penalaran untuk memvalidasi pemikiran kita, maka kita meningkatkan rasa percaya diri dengan matematika dan berpikir secara matematika (Siswanti dan Siti, 2016:91)

Namun kenyataan yang terjadi kemampuan penalaan matematis siswa masih tergolong rendah seperti studi yang dilakukan oleh Priatna (dalam Madio, 2016:2) mengenai penalaran matematis, diperoleh temuan bahwa kualitas kemampuan penalaran (analogi dan generalisasi) rendah karena skornya hanya 49\% dari skor ideal. Hal ini selaras dengan hasil wawancara yang telah peneliti lakukan pada tanggal 14 September 2020 dengan guru matematika disekolah tersebut didapat informasi bahwa kemampuan penalaran siswa dalam mempelajari matematika masih rendah. Banyak siswa yang belum bisa memahami maksud dari soal tersebut. Siswa belum bisa menarik kesimpulan dari suatu permasalahan. Dari beberapa permasalahan tersebut terlihat bahwa siswa masih rendah dalam hal kemampuan penalaran matematisnya.

Menurut Rohmad (dalam Afinnas, dkk, 2018:197) bila kemampuan bernalar tidak dikembangkan pada siswa, maka bagi siswa matematika hanya akan menjadi materi yang mengikuti serangkaian prosedur dan menirucontoh-contoh tanpa mengetahui maknanya. Dengan memiliki kemampuan penalaran matematika yang memadai, diharapkan para peserta didik akan mampu mendalami berbagai disiplin ilmu yang menjadi keahliannya, terutama ilmu yang terkait dengan teknologi. Pada akhirnya, dengan menguasai matematika, anak bangsa akan sanggup menghadapi perubahan zaman, dan mampu bersanding serta bersaing dengan bangsa lain dalam pengembangan sains dan teknologi (Kamarullah, 2017:22). Kurangnya kemampuan penalaran matematis siswa juga dipengaruhi oleh beberapa faktor seperti gaya belajar, kecemasan matematika instruksi, kurangnya rasa percaya diri, kepercayaan guru, lingkungan, kurangnya perhatian orang tua, serta jenis kelamin (Afif, dkk, 2016:329). Untuk mencapai hasil belajar matematika antara lain penalaran matematik siswa selain mengikuti petunjuk guru siswa juga perlu mengatur cara belajarnya sendiri, menata dirinya dalam belajar, bersikap, bertingkah laku, dan mengambil keputusan yang sesuai dengan 
kehendaknya sendiri (Mulyana dan Utari 2015:41). Maka dalam meningkatkan kemampuan penalaran matematis harus memperhatikan faktor-faktor yang dapat mempengaruhi anak baik itu melalui eksternal dan internal. Kemampuan siswa ini dapat dikembangkan dengan maksimal apabila guru mengetahui gaya belajar setiap siswanya.

Prashign (dalam Mulyati, 2015:2) mengatakan bahwa kunci menuju keberhasilan dalam belajar dan bekerja adalah mengetahui gaya belajar atau bekerja yang unik dari setiap orang, menerima kekuatan sekaligus kelemahan diri sendiri dan sebanyak mungkin menyesuaikan preferensi pribadi dalam setiap situasi pembelajaran, pengkajian maupun pekerjaan. Kemampuan dan gaya belajar seseorang untuk memahami dan menyerap pelajaran pada saat proses belajar sudah pasti berbeda tingkatnya, ada yang cepat, sedang dan ada pula yang sangat lambat. Untuk memaksimalkan kemampuan siswa dalam menyerap, mengatur dan mengolah informasi, terlebih dahulu dikenali gaya belajar dari siswa tersebut yaitu visual, auditorial atau kinestetik (Ridwan, 2017: 195).

Penelitian yang dilakukan oleh Khoirun Nisah (2018) mengenai hubungan kemampuan penalaran matematis dengan gaya belajar siswa setelah dilakukan perhitungan secara statistik maka diperoleh informasi bahwa kemampuan penalaran matematis siswa mempunyai hubungan yang signifikan dengan gaya belajar siswa, Gaya belajar memberikan sumbangsih sebesar 35,60\% terhadap kemampuan penalaran matematis siswa, sedangkan sisanya dipengaruhi oleh faktor-faktor lain. Akan tetapi tidak semua siswa dengan gaya belajar yang sama mempunyai kemampuan penalaran yang sama pula.

Uraian diatas menjadi dasar bagi peneliti untuk melakukan penelitian dengan judul "Analisis Kemampuan Penalaran Matematis Ditinjau Dari Gaya Belajar Siswa SMPIT Al-Falah Bandungan Tahun Ajaran 2020/2021". Berdasarkan ulasan latar belakang di atas maka tujuan peneliti mengadakan penelitian ini yaitu (1) Mengetahui profil kemampuan penalaran matematis siswa SMPIT Al-Falah Bandungan. (2) Mengetahui profil gaya belajar visual, auditorial dan kinestetik siswa SMPIT Al-Falah Bandungan. (3) Mengetahui korelasi kemampuan penalaran dengan gaya belajar siswa SMPIT Al-Falah Bandungan.

\section{METODE}

Jenis penelitian adalah penelitian kuantitatif non eksperimental dengan menggunakan metode korelasi. Salah satu desain penelitian yang digunakan pada penelitian non- eksperimen adalah korelasional, teknik yang digunakan dalam memperoleh data pada penelitian ini adalah dengan menggunakan angket gaya belajar dan tes kemampuan penalaran matematis siswa.

Penelitian ini dilaksanakan di SMPIT Al-Falah Bandungan yang terletak di Jl. AmbarawaBandungan Km.05, Dusun Ngawinan, Kelurahan Bandungan Jetis, Kec. Bandungan Semarang, Jawa Tengah dengan Kode Pos 50665. Penelitian ini dilaksanakan pada semester ganjil tahu pelajaran 2020/2021 yaitu pada tanggal 10 September sampai dengan 02 Oktober 2020.

Populasi dalam penelitian ini adalah seluruh siswa kelas VIII SMPIT Al-Falah Bandungan Tahun Ajaran 2020/2021 dengan jumlah 89 siswa. Sedangkan sampel dalam penelitian ini adalah siswa kelas VIII C. Pada penelitian ini teknik penarikan sampel yang digunakan adalah purposive sampling. 
Adapun variabel dalam penelitian ini terdiri dari variabel independent atau variabel bebas dan variabel dependent atau variabel terikat. Variabel bebas dalam penelitian ini adalah gaya belajar dan untuk variabel terikatnya adalah kemampuan penalaran matematis.

Instrumen yang digunakan adalah soal tes kemampuan penalaran matematis berupa soal uraian dan angket gaya belajar yang dimodifikasi dari dari penelitian terdahulu yang telah diujicobakan dan digunakan oleh Utami dan Meliasari.

Metode pengumpulan data yang digunakan dalam penelitian ini adalah metode dokumentasi, observasi, tes dan angket. Metode dokumentasi digunakan untuk mencari data mengenai hal-hal atau variabel yang berupa catatan, transkrip, buku, dan sebagainya. Metode observasi digunakan untuk menggali data dari sumber yang berupa tempat, aktivitas, benda atau rekaman gambar (Nugrahani, 2014:295), tes dalam penelitian ini peneliti bermaksud untuk mengetahui kemampuan penalaran matematis siswa SMPIT Al-Falah Bandungan menggunakan Butir Soal Tes dengan memperhatikan indikator kemampuan penalaran matematika, dan yang terakhir metode angket digunakan untuk memperoleh informasi dari responden dalam arti laporan tentang pribadinya, atau hal-hal yang ia ketahui (Nasution, 2016:68)

Data penelitian dianalisis menggunakan teknik analisis deskriptif kuantitatif dan Uji hipotesis korelasi product moment.

\section{Analisis Deskriptif}

Dalam menyusun distribusi frekuensi, Suharsimi Arikunto (2010: 294) mengemukakan langkah- langkah untuk membuat tabel distribusi frekuensi yaitu:

a. Mengidentifikasi Nilai Tertinggi dan Terendah.

b. Menentukan Rentang Nilai (R)

Rentang Nilai (R) mengurangkan nilai paling tinggi dengan nilai paling rendah.

$\mathrm{R}=$ Skor Tertinggi - Skor Terendah

c. Menentukan Banyaknya Kelas

Rumus dari Sturges yaitu:

$\mathrm{k}$ (banyak kelas) $=1+3,3 \log \mathrm{n}(\mathrm{n}=$ banyak subjek) dan lebar kelas (i) $=R \div k$

d. Masukan nilai skor pada tabel.

Kemudian kelompok yang paling banyak jumlahnya, ditunjukkan oleh prosentase yang tertinggi dengan menggunakan pengkategorian dengan pedoman sebagai berikut:

Tinggi: $X \geq M i+1 . S i$

Sedang: $M i+1 . S i>X \geq M i-1 . S i$

Rendah: $X<M i-1 . S i$

Untuk angket gaya belajar menggunakan sala likert dengan jumlah pilihan terdiri dari 4 alternatif jawaban, kemudian menentukan nilai maksimal $=4$ dan skor minimal $=1$, kelompok yang paling banyak jumlahnya, di tunjukkan oleh prosentase yang tertinggi dan kemudian sebaliknya. Selanjunya menghitung besarnya presentase gaya belajar siswa (Visual, Auditori, Kinestetik) menggunkan rumus presentase berikut:

$$
P=\frac{F}{N} \times 100 \%
$$


Keterangan:

P: Persentase

F: Frekuensi yang sedang dicari persentasenya

$\mathrm{N}$ : Number of Cases (Jumlah Subjek)

(Sudijono, 2010: 43)

\section{Uji Hipotesis}

Untuk mengetahui hubungan antara variabel bebas dan variabel terikat digunakan rumus korelasi product moment.

$$
r_{\text {hitung }}=\frac{n \sum x y-\left(\sum x\right)\left(\sum y\right)}{\sqrt{\left[n \sum x^{2}-\left(\sum x\right)^{2}\right]\left[n \sum y^{2}-\left(\sum y\right)^{2}\right]}}
$$

Keterangan:

$r_{\text {hitung }}=$ koefisien korelasi antara variabel $\mathrm{x}$ dan $\mathrm{y}$

$\mathrm{n} \quad=$ jumlah responden

$\sum \mathrm{x} \quad=$ jumlah skor tiap item

$\sum \mathrm{y} \quad=$ jumlah skor total (seluruh item)

$\sum x y \quad=$ jumlah hasil perkalian antara skor $\mathrm{x}$ dan $\mathrm{y}$

untuk mengetahui apakah hubungan dari kedua variabel signifikan, maka dilakukan uji signifikan dengan menggunakan rumus sebagai berikut:

$$
t=\frac{r_{x y} \sqrt{n-2}}{\sqrt{1-\left(r_{x y}\right)^{2}}}
$$

(Sumber: Sugiyono, 2015:257)

Keterangan:

$r_{x y}=$ Nilai koefisien korelasi antara variabel $\mathrm{x}$ dan $\mathrm{y}$

$\mathrm{n} \quad=$ Jumlah responden

Dilanjutkan dengan menghitung koefisien determinasi Untuk mengetahui seberapa besar kekuatan hubungan kemampuan penalaran matematis terhadap gaya belajar siswa, menggunakan rumus koefisien determinasi $r^{2} \times 100 \%$ dengan mengkuadratkan hasil perhitungan dari korelasi kemudian dikalikan dengan 100\%.

\section{HASIL DAN PEMBAHASAN}

Pengumpulan data tentang gaya belajar siswa peneliti menggunakan angket, sedangkan untuk mengumpulkan hasil belajar mahasiswa peneliti menggunakan hasil dari tes soal kemampuan penalaran matematis. Berikut disajikan hasil penelitian tersebut.

Untuk profil kemampuan penalaran matematis diketahui bahwa presentase mengenai hasil tes 
kemampuan penalaran matematis siswa dapat diambil kesimpulan bahwa dari 30 responden, 4 siswa dengan prosentase 13\% memiliki tingkat kemampuan penalaran matematis yang tinggi. Untuk lebih jelasnya berikut disajikan tabel pengkategorian hasil penelitian tes kemampuan penalaran matematis.

Tabel 1. Kriteria Kemampuan Penalaran Matematis Siswa

\begin{tabular}{|c|c|c|c|c|}
\hline No & Pedoman Skor & Ket & Frek & Persentase \\
\hline 1 & $X \geq M i+1$. Si $X \geq 64$ & Tinggi & 4 & $13 \%$ \\
\hline 2 & $\begin{array}{c}M i+1 . S i>X 64>X \\
\geq M i-1 . S i \quad \geq 47\end{array}$ & Sedang & 15 & $50 \%$ \\
\hline 3 & $X<M i-1$ Si $X<47$ & Rendah & 11 & $37 \%$ \\
\hline \multicolumn{3}{|c|}{ Total } & 30 & $100 \%$ \\
\hline
\end{tabular}

Dari perhitungan diperoleh mean sebesar 50.07. Jika dimasukkan maka harga mean tersebut masuk kedalam kriteria sedang. Maka dapat di ambil kesimpulan bahwa tingkat kemampuan penalaran matematis siswa SMPIT Al-Falah Bandungan termasuk dalam kategori sedang.

Kemudian untuk profil gaya belajar visual, auditorial dan kinestetik diketahui dari hasil penelitian unuk keseluruhan garis besar gaya belajar dikethui bahwa dari 30 orang siswa sebanyak 12 siswa dengan prosentase $40 \%$ memiliki gayabelajar visual, sebanyak 11 siswa dengan prosentase $37 \%$ memiliki gaya belajar auditori, sebanyak 5 siswa dengan prosentase $17 \%$ memiliki gaya belajar kinestetik, dan sebnayka 2 siswa memiliki gaya belajar kombinasi yaitu 1 siswa dengan prosentase 3\% gaya belajar kombinasi Visual-Kinestetik dan 1 siswa dengan prosentase 3\% gaya belajar VisualAuditori. Untuk lebih jelasnya berikut disajikan tabel pengkategorian gaya belajar siswa hasil dari angket gaya belajar siswa.

Tabel 2. Tingkat Kategori Gaya Belajar Siswa

\begin{tabular}{lllll}
\hline No & Gaya Belajar & Frek & Persentase & Ket \\
\hline 1 & Visual & 12 & $40 \%$ & Sangat Tinggi \\
2 & Auditori & 11 & $37 \%$ & Tinggi \\
3 & Kinestetik & 5 & $17 \%$ & Sedang \\
4 & Visual- Kinestetik & 1 & $3 \%$ & Rendah \\
5 & Visual- Auditori & 1 & $3 \%$ & Rendah \\
\hline
\end{tabular}

Disimpulkan bahwa kecenderungan gaya belajar siswa kelas VIII SMPIT Al-Falah Bandungan adalah gaya belajar visual dengan kategori sangat tinggi.

Gaya belajar visual diketahui bahwa dari 30 responden, 9 siswa dengan prosentase 30\% tergolong dalam gaya belajar visual kategori tinggi, 14 siswa dengan prosentase $47 \%$ tergolong dalam gaya belajar visual kategori sedang dan 7 siswa denga prosentase $23 \%$ tergolong dalam gaya belajar visual kategori rendah. Hal ini dapat dilihat pada tabet berikut 
Tabel 3. Tingkat Kategori Gaya Belajar Visual Siswa

\begin{tabular}{|c|c|c|c|c|c|}
\hline No & Pedoman & Skor & Ket & Frek & Persentase \\
\hline 1 & $X \geq M i+1 . S i$ & $x \geq 23$ & Tinggi & 9 & $30 \%$ \\
\hline 2 & $\begin{array}{c}M i+1 . S i>X \\
\geq M i-1 . S i\end{array}$ & $\begin{array}{c}23>X \\
\geq 19\end{array}$ & Sedang & 14 & $47 \%$ \\
\hline 3 & $X<M i-1 . S i$ & $X<19$ & Rendah & 7 & $23 \%$ \\
\hline \multicolumn{4}{|c|}{ Total } & 30 & $100 \%$ \\
\hline
\end{tabular}

Kecenderungan skor variabel gaya belajar visual bisa dilihat pada besarnya presentase, Maka dapat di ambil kesimpulan bahwa kategori gaya belajar visual siswa kelas VIII SMPIT Al-Falah Bandungan termasuk dalam kategori sedang dengan prosentase $47 \%$.

Untuk gaya belajar auditorial diketahui bahwa dari 30 responden, 8 siswa dengan prosentase $27 \%$ tergolong dalam gaya belajar auditori kategori tinggi, 13 siswa dengan prosentase 43\% tergolong dalam gaya belajar auditori kategori sedang dan 9 siswa dengan prosentase $30 \%$ tergolong dalam gaya belajar auditori kategori rendah. Hal ini dapat dilihat pada tabet berikut.

Tabel 4. Tingkat Kategori Gaya Belajar Auditorial Siswa

\begin{tabular}{|c|c|c|c|c|c|}
\hline No & Pedoman & Skor & Ket & Frek & Persentase \\
\hline 1 & $X \geq M i+1 S i$ & $X \geq 24$ & Tinggi & 8 & $27 \%$ \\
\hline 2 & $\begin{array}{c}M i+1 . S i>X \\
\geq M i-1 . S i\end{array}$ & $\begin{array}{c}24>X \\
\geq 18\end{array}$ & Sedang & 13 & $43 \%$ \\
\hline 3 & $X<M i-1 . S i$ & $X<18$ & Rendah & 9 & $30 \%$ \\
\hline \multicolumn{4}{|c|}{ Total } & 30 & $100 \%$ \\
\hline
\end{tabular}

Dapat dilihat dari hasil perhitungan bahwa kecenderungan gaya belajar auditorial siswa kelas VIII SMPIT Al-Falah Bandungan termasuk dalam kategori sedang dengan prosentase 43\%.

Untuk gaya belajar kinestetik dari 30 responden, 12 siswa dengan prosentase $40 \%$ tergolong dalam gaya belajar kinestetik kategori tinggi, 10 siswa dengan prosentase 33\% tergolong dalam gaya belajar kinestetik kategori sedang dan 8 siswa dengan prosentase $27 \%$ tergolong dalam gaya belajar kinestetik kategori rendah. Hal ini dapat dilihat pada tabe berikut.

Tabel 5. Tingkat Kategori Gaya Belajar Kinestetik Siswa

\begin{tabular}{|c|c|c|c|c|}
\hline No & Pedoman Skor & Ket & Frek & Persentase \\
\hline 1 & $X \geq M i+1$ Si $X \geq 22$ & Tinggi & 12 & $40 \%$ \\
\hline 2 & $\begin{array}{c}M i+1 . S i>X 22>X \\
\geq M i-1 . S i \quad \geq 18\end{array}$ & Sedang & 10 & $33 \%$ \\
\hline 3 & $X<M i-1$ Si $X<18$ & Rendah & 8 & $27 \%$ \\
\hline \multicolumn{3}{|c|}{ Total } & 30 & $100 \%$ \\
\hline
\end{tabular}


Jadi dapat disimpulkan bahwa kecenderungan gaya belajar kinestetik siswa kelas VIII SMPIT Al-Falah Bandungan termasuk dalam kategori tinggi dengan prosentase $40 \%$.

\section{Uji Normalitas}

Uji normalitas dapat diketahui dengan ketentuan apabila $L_{O}<L_{\text {tabel }}$ pada taraf signifikan $5 \%$ atau 0,05 . Berdasarkan perhitungan yang telah dilakukan maka nilai untuk $L_{O}$ untuk data kemampuan penalaran dengan $n=30$ adalah 0.089823. jika dibandingkan dengan harga $L_{\text {tabel }}=0.161$, maka diperoleh informasi bahwa $L_{O}<L_{\text {tabel }}$ atau setara dengan $0.089823<0.161$. Untuk data gaya belajar siswa diperoleh $L_{O}=0.057189$ dengan $n=30$. Jika dibandingkan dengan nilai $L_{\text {tabel }}=0.161$, maka diketahui bahwa $L_{O}<L_{\text {tabel }}$ atau setara dengan $0.057189<0.161$.

Tabel 6. Uji Normalitas

\begin{tabular}{lccc}
\hline \multicolumn{1}{c}{ Instrumen } & $\boldsymbol{L}_{\boldsymbol{O}}$ & $\boldsymbol{L}_{\text {tabel }}$ & Ket \\
\hline Kemampuan Penalaran Matematis & 0.089823 & 0.161 & B.Normal \\
Gaya Belajar & 0.057189 & 0.161 & B.Normal \\
\hline
\end{tabular}

Dari data yang telah diperoleh tersebut maka dapat disimpulkan bahwa data kemampuan penalaran matematis dan gaya belajar berdistribusi normal dan bisa mewakili populasi yang ada.

Uji hipotesis peneliti hitung menggunakan rumus product moment diperoleh $r_{\text {hitung }}=$ 0.435646. selanjutnya membandingkan harga $r$ product moment dengan $n=30$ yaitu sebesar 0.3610. Kemudian berdasarkan ketentuan analisis bahwa ketika $r_{\text {hitung }} r_{\text {tabel }}$ maka hipotesis diterima dan dapat disimpulkan bahwa terdapatnya hubungan kemampuan penalaran matematis dengan gaya belajar yang signifikan.

Selanjutnya, untuk menguji signifikansi antara antara hasil tes kemampuan penalaran matematis dengan gaya belajar siswa yaitu dengan nilai korelasi sebesar 0.435646 , dalam penelitian ini menggunakan taraf signifan $\alpha=5 \%$ dengan derajat kebebasan $d k=n-2$, maka hasil dari perhitungan terssebut diketahui $t_{\text {hitung }}=2.561$, kemudian $t_{\text {tabel }}$ dengan $n=30$ dan $t_{\text {tabel }}=$ 1.701, maka dapat disimpulkan bahwa hasil perhitungan signifikan, karena $t_{\text {hitung }}=2.561>$ $t_{\text {tabel }}=1.701$ pada taraf signifikansi $5 \%$. Kemudian, pada hasil perhitungan untuk mengetahui seberapa besar prosentase hubungan antara dua variabel maka menggunakan nilai koefisien determinan dan didapatkan nilai sebesar 19\%, hal tersebut membuktikan kalau 19\% kemampuan penalaran matematis siswa ditentukan oleh gaya belajar, dan sisanya ditentukan oleh faktor lain yang tidak dijelaskan dalam penelitian ini. 


\section{SIMPULAN}

Berdasarkan hasil analisis data penelitian dan deskripsi diatas maka dapat diambil kesimpulkan bahwa:

1. Kemampuan penalaran matematis memperoleh rata-rata sebesar sebesar 50.07 yang menunjukkan bahwa kecenderungan tingkat kemampuan penalaran matematis tersebut masuk kedalam kriteria sedang dengan prosentase 50\% sebanyak 15 siswa dari 30 responden. Kemudian untuk tingkatan kategori tinggi diketahui terdapat 4 siswa dengan prosentase 13\%, dan11 siswa denga prosentase 37\% memiliki tingkat kemampuan penalaran matematis yang rendah.

2. Hasil analisis dari gaya belajar diketahui bahwa siswamemiliki gaya belajar yang bervariasi yaitu Visual, Auditorial, dan Kinestetik. kecenderungan gaya belajar yang digunakan adalah visual dengan prosentase 40\% sebanyak 12 siswa dari 30 responden. Untuk gaya belajar auditori 11 siswa dengan prosentase $37 \%$, dan 5 siswa dengan prosentase $17 \%$ memiliki gaya belajar kinestetik. Terdapat 2 siswa yang memiliki gaya belajar gabungan, yaitu 1 siswa dengan variasi gaya belajar V-K (visual-kinestetik) dan 1 siswa dengan variasi gaya belajar V-A (visualauditorial).

3. Selanjutnya setelah dilakukan perhitungan secara statistik maka diperoleh informasi bahwa kemampuan penalaran matematis siswa mempunyai hubungan yang signifikan dengan gaya belajar siswa, hal ini dapat dilihat dari hasil perhitungan signifikan karena $t_{\text {hitung }}=$ $2.561>t_{\text {tabel }}=1.701$ pada taraf signifikansi 5\%. Hubungan kemampuan penalaran matematis terhadap gaya belajar siswa berada pada interval kuat dengan nilai 0.435646 dan taraf signifikan korelasi sebesar 2.561 dengan tingkat hubungan sebesar 19\% hal tersebut membuktikan kalau 19\% kemampuan penalaran matematis siswa ditentukan oleh gaya belajar, dan sisanya ditentukan oleh faktor lain. Akan tetapi tidak semua siswa dengan gaya belajar yang sama mempunyai kemampuan penalaran yang sama pula. Hal tersebut dapat dipengaruhi oleh berbagai faktor.

\section{DAFTAR PUSTAKA}

Afif, A. M. S., Suyitno, H., \& Wardono, W. (2017). Analisis Kemampuan Penalaran Matematis Ditinjau dari Gaya Belajar Siswa dalam Problem Based Learning (PBL). PRISMA, Prosiding Seminar Nasional Matematika, 328-336.

Afinnas, F. T., Masrukan, M.,\& Kurniasih, A. W. 2018. Analisis Kemampuan Penalaran Matematis Siswa dengan Model Self-Regulated Learning Menggunakan Asesmen Kinerja Ditinjau dari Metakognisi. PRISMA, Prosiding Seminar Nasional Matematika, 1, 197-207.

Ardhiyanti, Elfrida. Sutriyono \& Fika Widya Pratama. 2019. Deskripsi Kemampuan Penalaran Siswa Dalam Pemecahan Masalah Matematika Pada Materi Aritmatika Sosial. Universitas Kristen Satya. Jurnal Cendekia: Jurnal Pendidikan Matematika, 3(1): 90-103. 
Handayani, Aprilia Dwi. 2013. Penalaran Kreatif Matematis. Universitas Nusantarapgri Kediri. Jurnal Pengajaran MIP A, 18(2): 161-166.

Kamarullah. 2017. Pendidikan Matematika Di Sekolah Kita. Al Khawarizmi: Jurnal Pendidikan dan Pembelajaran Matematika. Kamarullah: Pendidikan Matematika di Sekolah Kita Al Khawarizmi, 1(1):21-32.

Latif, Sriwahyuni. Irwan Akib. 2016. Mathematical Connection Ability Insolving mathematics problem based On Initial Abilities of Students at Smpn 10 Bulukumba. Universitas Negeri Makassar. Jurnal Daya Matematis, 4(2): 207- 217

Madio, Sukandar Sukanto. 2016. Pengaruh Pembelajaran Berbasis Masalah Terhadap Kemampuan Penalaran Dan Komunikasi Matematis Siswa Smp Dalam Matematika. Stkip Garut. Jurnal Pendidikan Matematika, 10(2): 1-16

Mulyana, Ade. Utari Sumarmo. 2015. "Meningkatkan Kemampuan Penalaran Matematik Dan Kemandirian Belajar Siswa Smp Melalui Pembelajaran Berbasis Masalah”. Jurnal Ilmiah STKIP Siliwangi Bandung. 9(1): 40-51.

Mulyati. 2015. Identifikasi Gaya Belajar Siswa Kelas V Sd Se-Gugus 3 Kecamatan Pengasih Kabupaten Kulon Progo Tabun Ajaran 2014/2015. Skripsi. Universitas Negeri Yogyakarta.

Nasution, Hamni Fadlilah. 2016. Instrumen Penelitian Dan Urgensinya Dalam Penelitian Kuantitatif. IAIN Padangsidimpuan. Jurnal Al-Masharif, 4(1): 59-75.

Nugrahani, Farida. 2014. Metode Penelitian Kualitatif dalam Penelitian Pendidikan Bahasa. Solo: Cakra Books.

Ridwan, Muhamad. 2017. Profil Kemampuan Penalaran Matematis Siswa Ditinjau Dari Gaya Belajar. Universitas Pendidikan Indonesia. Jurnal Pendidikan Matematika KALAMATIKA, 2(2):193-206.

Siswanti, Rina Elok dan Siti Khabibah. 2016. Penalaran Siswa dalam Memecahkan Masalah Matematika Ditinjau dari Perbedaan Jenis Kelamin. Universitas Negeri Matematika. Jurnal Ilmiah Pendidikan Matematika, 2(5): 90-99.

Sudijono, Anas. 2010. Pengantar Statistik Pendidikan. Jakarta: PT Raja Grafindo Persada.

Suharsimi Arikunto. 2010. Manajemen Penelitian. Jakarta: Rineka Cipta.

Sugiyono. 2015. Metode penelitian pendidikan pendekatan kuantiatif, kualitatif dan R \& D. Bandung: Alfabeta. 